UDC 378.036:74(477.87)

DOI https://doi.org/10.24919/2308-4863/34-3-29

\begin{abstract}
Myroslava ZYMOMRYA, orcid.org/0000-0003-3564-6103

Candidate of Pedagogical Sciences, Associate Professor at the Department of English Language Practice Drohobych Ivan Franko State Pedagogical University (Drohobych, Lviv region, Ukraine) myroslava.zymomrya@gmail.com
\end{abstract}

\author{
Olena ZYMOMRYA, \\ orcid.org/0000-0001-7206-0190 \\ Candidate of Philological Sciences, \\ Associate Professor at the Department of International Communication \\ Uzhhorod National University \\ (Uzhhorod,Ukraine) olena.zymomrya@uzhnu.edu.ua
} Lesia SHAHALA,
orcid.org/0000-0002-3518-0270
Senior Lecturer at the Department of Germanic Languages and Translation Studies
Drohobych Ivan Franko State Pedagogical University
(Drohobych, Lviv region, Ukraine) sha_le@ukr.net

\title{
THE FOLK CRAFTS OF THE TRANSCARPATHIAN REGION IN THE CONTEXT OF FOLK TRADITIONS: AESTHETIC EDUCATION ASPECT
}

In the education system of Ukraine are being actively discussed actualization prospects of ethnic and cultural traditions. The study of national culture is one of the important problems of contemporary pedagogy. This is due to the fact that it is impossible to create a new art of the educational system without the knowledge of the origins of folk art. The article highlights the topical problem of the development of folk crafts in Transcarpathia in the context of national traditions. The most common varieties of handicrafts have been represented by embroidery, weaving, carpet weaving, pottery, wood carving, forging, embossing, art casting. The images represented on the products of craftsmen are in unison with motifs from folk songs, ballads, kolomyiky (short folk songs often combined with dancing), prypovidky (humorous sayings, often rhymed), tales. Folk art is naturally based on its organic connection with the customs and traditions. In their basis, there is a high aesthetic potential which is filled with motifs from different localities of the region. The handicrafts of Transcarpathia present a vivid focus on folk traditions. Decorative and applied art demonstrates its organic connection with the national arts and serves as their identifier in the context of typological comparison of the objects of handycraft industry of different nations. A certain exception is made by the model of traditions, customs and rites which belongs to related or unrelated peoples on the one hand, and neighboring nations, - on the other. In this case, we may speak about a key to the mutual influence that is possible between spiritually close nations. Since, the same perception of images, motifs and thematic solutions is not a rare case with them. This, for example, applies to the embroidery technology in different parts of Transcarpathia: counting satin stitch, art satin stitch, counting embroidery, cross stitching. For centuries, the best traditions perfected and passed down from generation to generation as standards of aesthetic, as part of the culture of the people. The pedagogical value of folk crafts is unquestionable.

Key words: folk crafts, Transcarpathia, national tradition, aesthetic education. 
Мирослава ЗИМОМРЯ,

orcid.org/0000-0003-3564-6103

кандидат педагогічних наук, дочент

кафедри практики англійської мови

Дрогобицького держсавного педагогічного університету імені Івана Франка (Дрогобич, Львівська область, Україна) myroslava.zymomrya@gmail.com

\author{
Олена ЗИМОМРЯ, \\ orcid.org/0000-0001-7206-0190 \\ кандидат філологічних наук, \\ доцент кафедри міжнародних комунікачій \\ Ужгородського начіонального університету \\ (Ужгород, Україна) olena.zутотrуа@иzhnи.еdи.иа \\ Леся ШАГАЛА, \\ orcid.org/0000-0002-3518-0270 \\ (Дрогобич, Львівська область, Україна) sha_le@ukr.net
}

старший викладач кафедри германських мов і перекладознавства

Дрогобицького державного педагогічного університету імені Івана Франка

\title{
НАРОДНІ ПРОМИСЛИ ЗАКАРПАТТЯ У КОНТЕКСТІ ФОЛЬКЛОРНИХ ТРАДИЦЙ: АСПЕКТ ЕСТЕТИЧНОГО ВИХОВАННЯ
}

\begin{abstract}
Народні промисли творять самобутню субкультуру, що охоплює різноманітні прояви духовних змагань народу. Це стосується також формування та розвитку народних промислів Закарпаття, де фольклорні традииії набули виразної домінанти. Важливу роль у ццьму відіграло народне мистецтво. Воно колоритне, багатогранне, самобутнє, звідси - його значення у культурно-національному житті украйнців, угорців, словаків, румунів, німців, вірмен, представників інших етносів, котрі проживають на Закарпатті. До найбільш поширених різновидів народних промислів належали і належать досі вишивки, ткацтво, килимарство, гончарство, різьба по дереву, кування, чеканка, художне литво. Образи, які містяться у виробах народних майстрів, суголосні мотивам із народних пісень, балад, коломийок, приповідок, казок, адже народне мистецтво закономірно опирається на органічний зв 'язок зі звичаями та традиціями. У їхній основі-високий естетичний потенціал, щзо наповнюється мотивами з різних населених пунктів регіону. 3-поміж них вирізняються такі міста і села, як Рахів, Ясіня, Великий Бичків, Тячів, Хуст, Міжгір'я, Берегове, Перечин, Іза, Копашньове. Тут нагромадився значний історичний досвід, який передається з покоління до покоління і животворить новими тенденціями. Таким чином, традиційна художня система щцодо побудови образу і техніки виконання спричиняє появу нових реалізацій, щзо мають як колективний, так і індивідуальний характер. У народних промислах Закарпаття міститься яскрава орієнтація на контекст фольклорних традицій. Декоративно-ужиткове мистецтво свідчить про його органічну сполуку з національним мистецттвом і слугує його ідентифікатором, якще говорити про типологічні зіставлення з виробами промислів різних народів. Декоративно-ужсткове мистеитво найкращчим чином співвідноситься з історією краю, його духовно-культурними традиціями, тому так важливо зберігати вироби народних умільців, переймати досвід попередніх поколінь із метою його опанування та примноження на новій основі з урахуванням інноваційних технологій. Усе ие покликане стимулювати творчу активність сучасників, насамперед представників молодшої та середньої вікової категорії- школярів і студентів, які реалізують проекти з декоративно-ужиткового мистецтва у художньо-прикладних гуртках. У подібних осередках відбувається природне прилучення гуртківців до духовних надбань начіональної культури, виховується бережливе ставлення до мови, історії, фольклорних традицій $і$ звичаӥв.
\end{abstract}

Ключові слова: народні промисли, Закарпаття, національні традиції, естетичне виховання.

Formulation of the problem. Folk crafts create a unique subculture that embraces the diversity of peoples' spiritual aspirations. This also applies to the formation and development of the handicrafts of Transcarpathia where folk traditions acquired particular distinctions in the twentieth century. Folk art played an important role in this process. It is colorful, multifaceted, and original. Hence, its importance in the cultural and national life of Ukrainians, Hungarians,
Slovaks, Romanians, Germans, Armenians and representatives of other ethnic groups living in this region (Bentsa, 2004; Zymomrya, 2013).

Research analysis. A review of the methodological literature has shown that the role of the folk crafts in the aesthetic education is an object of interest for many scientists. Various aspects of this problem are emphasized by the researchers Y. Bahley, Ya. Bayrak, I. Bermes, I. Khlanta, M. Klyap, H. Reho, T. Rosul, V. Saharda, 
V. Tytarenko, A. Voloshchuk, M. Zan, O. Yurosh and others. The study of national culture is one of the important problems of contemporary pedagogy.

The purpose of the article. The aim of our investigation is to reveal the importance of the folk crafts of the Transcarpathian region in the aesthetic education.

The presentation of the material. The most common varieties of handicrafts have been represented by embroidery, weaving, carpet weaving, pottery, wood carving, forging, embossing, art casting. The images represented on the products of craftsmen are in unison with motifs from folk songs, ballads, kolomyiky (short folk songs often combined with dancing), prypovidky (humorous sayings, often rhymed), tales. Folk art is naturally based on its organic connection with the customs and traditions. In their basis, there is a high aesthetic potential which is filled with motifs from different localities of the region.

The following towns and villages are among them: Rakhiv, Yasinia, Velykyi Bychkiv, Tiachiv, Hust, Mizhhiria, Berehove, Perechyn, Iza, Kopashniove. Considerable historical experience has been accumulated in these places; it is passed on from generation to generation and gives life to new trends. Thus, the traditional art system of creating images and special technique leads to the appearance of new creations which are of both collective and individual character, the latter one being of major importance.

The activities of the Transcarpathian Regional House of Folk Art (founded in November, 1945), testify to the fact. It was headed by Andriy Kotska (1911-1987) who received the title of the People's Artist of Ukraine. In the 1950's - 1990's, Evhen Sherehiy (1910-1985), Vasyl Poliak (1929-1982), Semen Poliak (1932-1988) and Vasyl Kobal (Zymomrya, 1996: 4) continued developing the traditions that were established by the outstanding bearer of the Transcarpathian school of painting after the reorganization of this cultural centre: 1980-1991 - Transcarpathian regional scientific and methodological center of folk art, cultural and educational activities, 1992-1996- House of folk art of Transcarpathia, since 1997 - Transcarpathian regional center of folk art.

It is noteworthy that such known figures of Ukrainian culture as artists Adalbert Erdeli (1891-1955) and Fedir Manailo (1910-1978) worked here as methodologists. Development issues and the popularization of folk crafts occupied an important place among the functions and tasks of the Transcarpathian regional center of folk art handicrafts. In the first place, those were the measures aimed at the spiritual growth, humanization of society, strengthening of transcendental values, compiling cultural and educational programs on the basis of the systemic accumu- lation of experience with an aim to spread the crafts and their use in the social and cultural activities of other art centers.

The Uzhhorod College of Applied Arts (founded in autumn, 1945) contributed to the development of handicrafts. It made a significant impact on strengthening the productive traditions of folk fine and applied arts in Transcarpathia. In this context, it is appropriate to mention the figure of Zoltan Bakoniy (1916-1989), the creator of an art studio in Uzhhorod. His artistic and educational system provided a thorough training of craftsmen through innovative approaches to artistic and aesthetic training involving the synthesis of both folk principles and traditions of European pedagogy (Voloshchuk, 2008: 6).

What are the key features of Transcarpathian handicrafts in terms of folklore traditions? Continuity of experience occupies the central place. To illustrate this, we can mention the development of ornamental compositions and consistency in decorating the pieces. In this regard, Transcarpathia's craftsmen achieved perfection as in the original ornaments on wooden works of art which are decorated by dry carving and inlay. All this enhances the beauty of the materials as well as the master's creativity.

The basic motifs, for example, used in handicraft weaving by $\mathrm{H}$. Vyzychkanych, are an integral component. A similar approach was characteristic of the master of poker-work from the region of Kosiv Ivan Hrymaliuk (1904-1989). As a rule, these motifs created an integral pattern, consisting of the components which were rhythmically repeated in the general composition of the product. The combination of the elements of carving and inlay on a flat surface of the "decorative cross" is no exception. It is typical of the carvers from the Hutsulschyna region (Vakh, 2005: 67) where craftsmen use the combination of colors technique.

In the light of folk traditions, the craftsmen's works - which used to be of practical everyday use - are of great artistic value. These are represented by pieces of home furniture, including tables, shelves, cradles, benches, stools, mysnyky (shelves for keeping plates and other dishes), beds; kitchen utensils - spoons, bowls, konovky (pails), konovtsi (mugs), heletky (small wooden barrels for milk, cottage cheese, etc.); goods for household use - kudelias (stick-like parts of a loom), combs, spindles, clamps, shuttles; objects of cult and for ritual purposes - candles, icons, crosses. According to Leonid Orshansky and Petro Andriiuk, "the emergence and development of artistic woodworking are closely related to the practical human activity" (Orshansky, 2002: 12). The results of our analysis confirm the objectivity of this conclusion. In fact, in Transcar- 
pathia there appeared a kind of stereotype which is based on the pragmatic understanding of the functions of the products used for the intended purpose. This has been proved by numerous designs of carpets, woven strips of carpets and pokrivtsy (covers), nalavnyky (carpet-like cloth for covering benches) which reflect the artistic traditions of weaving.

The handicrafts of Transcarpathia present a vivid focus on folk traditions. Decorative and applied art demonstrates its organic connection with the national arts and serves as their identifier in the context of typological comparison of the objects of handycraft industry of different nations. A certain exception is made by the model of traditions, customs and rites which belongs to related or unrelated peoples on the one hand, and neighboring nations, - on the other. In this case, we may speak about a key to the mutual influence that is possible between spiritually close nations. Since, the same perception of images, motifs and thematic solutions is not a rare case with them. This, for example, applies to the embroidery technology in dif- ferent parts of Transcarpathia: counting satin stitch, art satin stitch, counting embroidery, cross stitching.

Conclusions. The analysis of the above material provides grounds to characterize the level of development and formation of the handicrafts of Transcarpathia in the context of their connection with folk traditions.

Decorative and applied art correlates best with the history of the region, its spiritual and cultural traditions. Therefore, it is important to preserve the works of craftsmen, learn from the previous generations with the aim of mastering and enrichment on a new basis by taking into account innovative technologies (Vyshnevskyi, 2010; Tytarenko, 2004). All this is to stimulate the creativity of modern people, primarily the younger and middle age generation (Antonovych, 1997: 5) - pupils and students who develop their art projects in the circles of decorative and applied arts. In these circles, a natural process of involving the youth in the development of the spiritual heritage of national culture takes place; they are educated to cherish their language, history, folk traditions and customs.

\section{BIBLIOGRAPHY}

1. Антонович С. Естетичне виховання підлітків засобами народного образотворчого мистецтва : автореф. дис. ... канд. пед. наук. Івано-Франківськ, 1997. 24 с.

2. Бенца О. Громадянське виховання учнівської молоді в спадщині діячів освіти Закарпаття (1919-1939 рр.). Дрогобич : Коло, 2004. $231 \mathrm{c.}$

3. Вах I. До історії дослідження географії народних художніх промислів на Гуцульщині. Історія украӥнської географії. Всеукраӥнський науково-теоретичний часопис. Тернопіль : Підручники і посібники, 2005. Вип. 2 (12). С. 66-69.

4. Вишневський О. Український виховний ідеал і національний характер (витоки, деформації і сучасні виклики). Дрогобич : Сурма, 2010. 160 с.

5. Волощук А. Мистецько-педагогічна система Золтана Баконія в контексті розвитку художньої освіти України та Закарпаття. Ужгород : Гражда, 2008. 64 с.

6. Зимомря М. Естетичне виховання молоді засобами народних промислів Закарпаття (1919-1939 рр.) : автореф. дис. ... канд. пед. наук. 13.00.01. Тернопіль, 2013. 19 с.

7. Зимомря М., Уральський Л. Осередок духовної культури Закарпаття. Ужгород, 1996. 16 с.

8. Оршанський Л., Андріюк П. Основи гуцульського художнього деревообробництва. Косів : Писаний Камінь, 2002. $236 \mathrm{c}$.

9. Титаренко В. Українські народні промисли: естетичні аспекти. Полтава : ACMI, 2004. 250 с.

\section{REFERENCES}

1. Antonovych Ye. Estetychne vykhovannia pidlitkiv zasobamy narodnoho obrazotvorchoho mystetstva [Aesthetic education of adolescents by means of folk art] (Candidate's thesis). Ivano-Frankivsk, 1997. 24 p. [in Ukrainian].

2. Bentsa O. Hromadianske vykhovannia uchnivskoi molodi v spadshchyni diiachiv osvity Zakarpattia (1919-1939 rr.) [Civic education of student youth in the legacy of Transcarpathian educators (1919-1939)]. Drohobych: Kolo, 2004. 231 p. [in Ukrainian].

3. Vakh I. Do istorii doslidzhennia heohrafii narodnykh khudozhnikh promysliv na Hutsulshchyni. Istoriia ukrainskoi heohrafii [To the history of the study of the geography of folk arts and crafts in the Hutsul region]. Vseukrainskyi naukovo-teoretychnyi chasopys. Ternopil: Pidruchnyky i posibnyky, 2005. Issue 2 (12). P. 66-69 [in Ukrainian].

4. Vyshnevskyi O. Ukrainskyi vykhovnyi ideal i natsionalnyi kharakter (vytoky, deformatsii i suchasni vyklyky) [Ukrainian educational ideal and national character (origins, deformations and modern challenges)]. Drohobych: Surma, $2010.160 \mathrm{p}$. [in Ukrainian].

5. Voloshchuk A. Mystetsko-pedahohichna systema Zoltana Bakoniia v konteksti rozvytku khudozhnoi osvity Ukrainy ta Zakarpattia [Art and pedagogical system of Zoltan Bakoni in the context of the development of art education in Ukraine and Transcarpathia]. Uzhhorod: Hrazhda, 2008. 64 p. [in Ukrainian].

6. Zymomrya M. Estetychne vykhovannia molodi zasobamy narodnykh promysliv Zakarpattia (1919-1939 rr.) [Aesthetic education of youth by means of folk crafts of Transcarpathia (1919-1939)]. (Candidate's thesis). Ternopil, 2013. 19 p. [in Ukrainian].

7. Zymomrya M., Uralskyi L. Oseredok dukhovnoi kultury Zakarpattia [Center of spiritual culture of Transcarpathia]. Uzhhorod, 1996. 16 p. [in Ukrainian].

8. Orshanskyi L., Andriiuk P. Osnovy hutsulskoho khudozhnoho derevoobrobnytstva [Fundamentals of Hutsul artistic woodworking]. Kosiv: Pysanyi Kamin, 2002. 236 p. [in Ukrainian].

9. Tytarenko V. Ukrainski narodni promysly: estetychni aspekty [Ukrainian folk crafts: aesthetic aspects]. Poltava: ASMI, 2004. 250 p. [in Ukrainian]. 